\title{
Improving the Effectivity of Urea Fertilizer in Shallot by Using Urease and Nitrification Inhibitors
}

\section{(Perbaikan Efektivitas Pupuk Urea Melalui Penghambat Aktivitas Urease dan Nitrifikasi pada Tanaman Bawang Merah)}

\author{
Sugiyanta ${ }^{1 *}$, Isna Tustiyani ${ }^{2}$, Diny Dinarti ${ }^{1}$ \\ (Diterima Maret 2019/Disetujui Agustus 2019)
}

\begin{abstract}
Nitrification inhibitors are used to decrease the rate of nitrification process so it can decreases the nitrate losses. The objective of this study was to investigate the improvement of urea effectiveness by using urease and nitrification inhibitors on shallot. The study was conducted at Blubuk Village, Tanjung, Brebes District, Central Java, Indonesia from December 2017 to April 2018. The experiment was arranged in a randomized block design with 8 treatments and 3 replications. The treatments were untreated group (P0), $100 \%$ dose of Urea without inhibitor (control) (P1), (3) 100\% dose of Urea + Urease Inhibitor (P2), 100\% dose of Urea + Nitrification Inhibitor (P3), 100\% dose of Urea + Urease Inhibitor + Nitrification Inhibitor (P4), $80 \%$ dose of Urea + Urease Inhibitor (P5), $80 \%$ dose of Urea + Nitrification Inhibitor (P6), and $80 \%$ dose of Urea + Urease Inhibitor + Nitrification Inhibitor (P7). The results showed that $100 \%$ dose of Urea + Urease inhibitor, $\mathbf{8 0} \%$ dose of Urea + Urease inhibitor, $\mathbf{8 0} \%$ dose of Urea + Nitrification inhibitor, and $80 \%$ dose of Urea + Urease inhibitor + Nitrification inhibitor treatments significantly produced higher plants heights, number of leaves, and more number of tillers compared to control treatment $(100 \%$ Urea without inhibitors), without affecting the yield and yield components.
\end{abstract}

Keywords: alluvial, fertilizer, Nitrobacter, nitrogen, Nitrosomonas

\section{ABSTRAK}

Zat penghambat aktivitas nitrifikasi digunakan untuk menurunkan proses nitrifikasi sehingga dapat menurunkan kehilangan pupuk nitrogen. Tujuan penelitian ini adalah untuk mempelajari perbaikan efektivitas pupuk urea melalui zat penghambat aktivitas urease dan nitrifikasi pada tanaman bawang merah. Penelitian dilaksanakan di Desa Blubuk, Kecamatan Tanjung, Kabupaten Brebes, Jawa Tengah, Indonesia dari bulan Desember 2017-April 2018. Rancangan penelitian menggunakan metode Rancangan Acak kelompok dengan 3 ulangan. Penelitian terdiri atas 8 perlakuan, yaitu tanpa perlakuan (P0), $100 \%$ dosis urea tanpa zat penghambat (kontrol) (P1), $100 \%$ dosis urea + zat penghambat urease (PU) (P2), 100\% dosis urea + zat penghambat nitrifikasi (PN) (P3), $100 \%$ dosis urea + PU + PN (P4), $80 \%$ dosis urea +PU (P5), $80 \%$ dosis urea +PN (P6), dan $80 \%$ dosis urea + PU + PN (P7). Hasil penelitian menunjukkan bahwa perlakuan $100 \%$ dosis urea $+\mathrm{PU}, 80 \%$ dosis urea $+\mathrm{PU}, \mathbf{8 0} \%$ dosis urea+PN, $80 \%$ dosis urea + $\mathrm{PU}+\mathrm{PN}$ nyata menghasilkan tinggi tanaman, jumlah daun, dan jumlah anakan lebih banyak dibandingkan kontrol, namun tidak berbeda nyata pada peubah komponen hasil dan hasil bawang merah.

Kata kunci: aluvial, Nitrobacter, nitrogen, Nitrosomonas, pupuk

\section{INTRODUCTION}

Nitrogen can be absorbed by the plant by converting ammonium to nitrite by Nitrosomonas spp. and then the conversion of nitrite to nitrate by Nitrobacter spp. In moderate temperature and high soil water content, nitrification occurs on most soils within a few days or weeks after application of ammonium sources (urine, manures, compost, or urea fertilizer) (IPNI 2018).

1 Departemen Agronomi dan Hortikultura, Fakultas Pertanian, Institut Pertanian Bogor. Kampus IPB Darmaga, Bogor 16680

2 Program Studi Agroteknologi, Universitas Garut. Lokasi Kampus I, Jl. Raya Samarang No. 52A Hampor-Tarogong, Garut 44151

* Penulis Korespondensi:

Email: mr_sugiyanta@yahoo.co.id
Nitrate is the usual form of $\mathrm{N}$ in soil that can be absorbed by plant. Nitrates are taken up by the roots and transferred to either water or the atmosphere. It can leach below the root zone. In addition, nitrate can be denitrified to form nitrous oxides and dinitrogen by the other soil bacteria, in waterlogged conditions. Nitrification is rapid in warm soils $\left(>25^{\circ} \mathrm{C}\right)$, and it mostly ceases below $5^{\circ} \mathrm{C}$. This process mostly happen in the soils that well aerated and near field capacity. Nitrification inhibitors are used to decrease the rate of nitrification process, so that decreases the nitrate losses (Nelson \& Huber 2001).

Urease inhibitors are some compounds added to urea that can reduce the rate of the first "hydrolysis" step, and ammonia production. Urea can be formulated as dry granules, pills, or as a fluid alone or mixed with ammonium nitrate (UAN) (Mohanty et al. 2008). The 
disadvantage of all forms of urea is the increasing loss of ammonia gas if it is not incorporated into the soil soon after application (IPNI 2018).

Urea is converted to ammonium bicarbonate by the urease enzyme which occurs naturally during a few days after application. When urea is hydrolyzed by the urease, most of the ammonium is stored at the site of soil cation exchange, the $\mathrm{pH}$ rises briefly, and ammonia gas is produced. Urea inhibitors that are generally used to reduce the transient enzyme activity and slow down the rate at which urea is hydrolyzed (Du et al. 2012) are hydroximate (Mishra et al. 2002), fluoride (Prakash \& Bhusha 1998), thiols (Todd \& Hausinger 1989), hydroxyureas (Uesato et al. 2004), biscoumarin (Khan et al. 2004), and natural extracts (Juszkiewicz et al. 2004). The most widely used urease inhibitor is $\mathrm{N}-(\mathrm{n}$ Butyl) thiophosphoric triamide (NBTPT or NBPT), which is converted into active $\mathrm{N}$-(n-Butyl) phosphate triamide (NBPTO or BNPO), phenylphosphorodiamidate (PPD/PPDA) and hydroquinone. Nitrification inhibitors slow down the process by inhibiting the activity of Nitrosomonas bacteria and increasing ammonium concentration. Urease and nitrification inhibitors are useful for reducing ammonia losses in urea fertilizer. They can control urea hydrolysis for 7 to 14 days, after rain, irrigation, or soil mixing. Urease and nitrification inhibitors are useful to keep the nitrogen fertilizer in the root zone, so the environmental condition is good. The good environmental conditions can increase plant growth and yield (Tustiyani et al. 2014; Kuswantoro 2016). The purpose of the research was to study the effect of urease and nitrification inhibitor on the effectiveness of nitrogen fertilization, growth, and yield of shallot.

\section{MATERIALS AND METHODS}

\section{Study Area and Materials}

This experiment was conducted at the Blubuk Village, Tanjung, Brebes District, Central Java, Indonesia with altitude $3 \mathrm{~m}$ above sea level, type of rainfall $\mathrm{E}$, alluvial type soil, with $\mathrm{pH} 4.8-5.23$ in December 2017 to April 2018. Soil analysis was carried out in the testing laboratory of the Agronomy and Horticulture Department, IPB University. The material used in this research was local variety of shallot seed ("Bima Kuning Brebes"), urease and nitrification inhibitors, Urea, Super Phosphate/SP-36 (36\% $\left.\mathrm{P}_{2} \mathrm{O}_{5}\right)$, and Muriate of Potash/MOP $\left(60 \% \mathrm{~K}_{2} \mathrm{O}\right)$. The tools used to process data were computer and statistical analysis program (SAS).

\section{Procedures}

\section{- Plant preparation}

Soil tillage was done perfectly until the land was ready to be planted. After soil tillage, then the beds are made with a width of $1 \mathrm{~m}$. The distance between the beds was about $50 \mathrm{~cm}$. One unit of testing consisted of 5 beds each with a long of $5 \mathrm{~m}$. Plant spacing used was
$20 \times 20 \mathrm{~cm}$ with 1 seedling/hole. Urease and nitrification inhibitors were applied at 10 DAP (Days After Planting), urea fertilizer was splitted in three times: $1 / 3$ dose of urea fertilizer was applied at $10 \mathrm{DAP}$, $1 / 3$ dose at $20 \mathrm{DAP}$, and the remainder at $30 \mathrm{DAP}$. SP36 was applied 1 week before planting $(300 \mathrm{~kg} / \mathrm{ha})$. MOP fertilizer at a dose of $200 \mathrm{~kg} / \mathrm{ha}$ applied twice, $50 \%$ dose was applied at $10 \mathrm{DAP}$ and the remainder at 30 DAP. Pest and disease controls were conducted according to the level of attacks with pesticides on a limited basis.

\section{- Observation}

Parameters observed in this study were (i) Plant height, the number of leaves, the number of tillers, were observed from 3-7 week after planting (WAP), (ii) soil analysis before and after treatment ( $\mathrm{N}$-total (Kjeldahl)), (iii) $\mathrm{N}$-Content and $\mathrm{N}$-Uptake (multiplication results from $\mathrm{N}$-content and dry weight/plant) in biomass after harvesting, (iv) the number of bulb per plant, (v) the weight of 10 bulbs, (vi) the yield per plant (wet and dry), and (vii) the yield per plot and yield per hectare.

\section{Data Analysis}

The study was designed as a completely randomized block design. The treatments were untreated (P0), $100 \%$ dose of Urea without inhibitor (control) (P1), $100 \%$ dose of Urea + Urease Inhibitor (P2), $100 \%$ dose of Urea + Nitrification Inhibitor (P3), $100 \%$ dose of Urea + Urease Inhibitor + Nitrification Inhibitor (P4), $80 \%$ dose of Urea + Urease Inhibitor (P5), $80 \%$ dose of Urea + Nitrification Inhibitor (P6), $80 \%$ dose of Urea + Urease Inhibitor + Nitrification Inhibitor (P7). Each treatment was repeated 3 times. One experimental unit was $25 \mathrm{~m}^{2}$. The data were analyzed statistically using F-test and Duncan's Multiple Range Test (DMRT) at 5\% significant level.

\section{RESULTS AND DISCUSSION}

\section{Shallot Plant Growth}

In general, the use of urease and nitrification inhibitors did not increase the effectiveness of Urea at the beginning of the growth period ( 3 and 4 WAP) of shallot (Table 1). At 5 WAP, $100 \%$ dose of Urea + Urease Inhibitor, $80 \%$ Urea + Urease Inhibitor, $80 \%$ Urea + Nitrification inhibitor, and $80 \%$ Urea + Urease inhibitor + Nitrification inhibitors treatments actually produced higher plants than the dose of $100 \%$ Urea without inhibitors (control). Reduction of urea dose up to $20 \%$ in treatment of $80 \%$ urea + Urease Inhibitor, $80 \%$ Urea + Nitrification Inhibitor, and $80 \%$ Urea + Urease Inhibitor+ Nitrification Inhibitor could produce significantly higher plant heights than the dose of $100 \%$ Urea without inhibitors treatment at 5 WAP. It showed that the use of Urease and Nitrification inhibitors could increase the effectiveness of urea in 5-6 WAP. The inhibitory effect is usually between 25 to 55 days, and the effectiveness is low when it is leaching (IPNI 2018). 
Table 1 The growth of shallot plant treated with urease and nitrification inhibitors

\begin{tabular}{|c|c|c|c|c|}
\hline Treatment & $3 \mathrm{WAP}$ & 4 WAP & 5 WAP & 6 WAP \\
\hline & \multicolumn{4}{|c|}{ Plant height $(\mathrm{cm})$} \\
\hline Untreated & $18.1^{d}$ & $22.7^{b}$ & $26.7^{\mathrm{c}}$ & $31.3 d$ \\
\hline $100 \%$ dose of Urea without inhibitor (control) & $21.3^{\mathrm{ab}}$ & $26.9^{a}$ & $31.5^{b}$ & $36.5 a b$ \\
\hline $100 \%$ dose of Urea + Urease Inhibitor & $20.7^{\mathrm{abc}}$ & $26.2^{a}$ & $38.5^{\mathrm{a}}$ & $35.2 \mathrm{bc}$ \\
\hline $100 \%$ dose of Urea + Nitrification Inhibitor & $21.9^{a}$ & $26.6^{a}$ & $31.3^{b}$ & $36.8 a b$ \\
\hline $\begin{array}{l}100 \% \text { dose of Urea + Urease Inhibitor + } \\
\text { Nitrification Inhibitor }\end{array}$ & $21.3^{a b}$ & $26.3^{a}$ & $32.1^{b}$ & $36.2 a b$ \\
\hline $80 \%$ dose of Urea + Urease Inhibitor & $20.3^{\mathrm{abc}}$ & $25.8^{a}$ & $38.7^{a}$ & $33.7 c$ \\
\hline \multirow{3}{*}{$\begin{array}{l}80 \% \text { dose of Urea + Nitrification Inhibitor } \\
80 \% \text { dose of Urea + Urease Inhibitor + Nitrification } \\
\text { Inhibitor }\end{array}$} & $19.7^{c}$ & $26.6^{a}$ & $39.2^{\mathrm{a}}$ & $35.7 \mathrm{bc}$ \\
\hline & $20.1^{\mathrm{bc}}$ & $27.0^{\mathrm{a}}$ & $39.0^{a}$ & $37.9 a$ \\
\hline & \multicolumn{4}{|c|}{ Number of leaves } \\
\hline Untreated & $8.5^{b}$ & $13.3^{\mathrm{c}}$ & $18.0^{\mathrm{b}}$ & $17.9 c$ \\
\hline $100 \%$ dose of Urea without inhibitor (control) & $8.9^{a b}$ & $13.9^{c}$ & $18.1^{b}$ & $18.3 c$ \\
\hline $100 \%$ dose of Urea + Urease Inhibitor & $8.9^{a b}$ & $17.2^{\mathrm{ab}}$ & $26.5^{\mathrm{a}}$ & 25.2ab \\
\hline $100 \%$ dose of Urea + Nitrification Inhibitor & $10.0^{\mathrm{ab}}$ & $14.5^{\mathrm{c}}$ & $18.5^{\mathrm{b}}$ & $19.2 b c$ \\
\hline $\begin{array}{l}100 \% \text { dose of Urea + Urease Inhibitor + } \\
\text { Nitrification Inhibitor }\end{array}$ & $9.2^{\mathrm{ab}}$ & $13.5^{c}$ & $17.7 b$ & $18.2 \mathrm{c}$ \\
\hline $\begin{array}{l}80 \% \text { dose of Urea + Urease Inhibitor } \\
80 \% \text { dose of Urea + Nitrification Inhibitor }\end{array}$ & $\begin{aligned} & 9.6^{\mathrm{ab}} \\
& 10.5^{\mathrm{a}}\end{aligned}$ & $\begin{array}{l}17.5^{\mathrm{ab}} \\
16.3^{\mathrm{b}}\end{array}$ & $\begin{array}{l}28.3 a \\
26.3 a\end{array}$ & $\begin{array}{l}27.7 a \\
25.3 a b\end{array}$ \\
\hline \multirow[t]{2}{*}{$\begin{array}{l}80 \% \text { dose of Urea + Urease Inhibitor + Nitrification } \\
\text { Inhibitor }\end{array}$} & $10.3^{a}$ & $18.5^{a}$ & 27.1a & 24.7ab \\
\hline & \multicolumn{4}{|c|}{ Number of tillers } \\
\hline Untreated & $4.5^{\mathrm{a}}$ & $4.5^{\mathrm{bcd}}$ & $4.5 b$ & $4.6 b$ \\
\hline $100 \%$ dose of Urea without inhibitor (control) & $4.3^{a}$ & $4.4^{\mathrm{cd}}$ & $4.5 b$ & $4.5 b$ \\
\hline $100 \%$ dose of urea + Urease inhibitor & $3.9^{a}$ & $5.2^{\mathrm{ab}}$ & $6.1 \mathrm{a}$ & $6.1 \mathrm{a}$ \\
\hline $100 \%$ dose of urea + Nitrification inhibitor & $4.5^{\mathrm{a}}$ & $4.6^{\mathrm{bcd}}$ & $4.7 \mathrm{~b}$ & $4.7 \mathrm{~b}$ \\
\hline $\begin{array}{l}100 \% \text { dose of urea }+ \text { Urease inhibitor }+ \\
\text { Nitrification inhibitor }\end{array}$ & $4.2^{\mathrm{a}}$ & $4.2^{d}$ & $4.3 b$ & $4.3 b$ \\
\hline $80 \%$ dose of urea + Urease inhibitor & $4.1^{\mathrm{a}}$ & $5.5^{\mathrm{a}}$ & $6.8 \mathrm{a}$ & $6.8 \mathrm{a}$ \\
\hline $80 \%$ dose of urea + Nitrification inhibitor & $4.4^{\mathrm{a}}$ & $4.9^{a b c}$ & $6.3 a$ & $6.3 a$ \\
\hline $\begin{array}{l}80 \% \text { dose of urea + Urease inhibitor + Nitrification } \\
\text { inhibitor }\end{array}$ & $4.3^{a}$ & $5.5^{\mathrm{a}}$ & $6.4 a$ & $6.5 a$ \\
\hline
\end{tabular}

Description: The numbers followed by the same letter in the same column are not significantly different according to DMRT on $5 \%$ level.

The effects of urease and nitrification inhibitors on the number of leaves and number of tillers on shallots were observed on 4 WAP (Table 1). $100 \%$ dose of urea + urease inhibitor, $80 \%$ dose of urea + urease inhibitor, $80 \%$ dose of urease + nitrification inhibitors, and $80 \%$ dose of Urea + Urease inhibitor + Nitrification inhibitor treatments consistently produced significantly higher number of leaves than the control treatment $(100 \%$ dose of Urea without inhibitors) in 4-6 WAP. The effects of inhibitors of both urease inhibitor and nitrification inhibitor were observeds in the variable of number of tillers. Shallot treated with urea fertilizers added with urease inhibitor and nitrification inhibitor produced higher number of tillers than those treated with urea without inhibitors. Shallot treated with $100 \%$ dose of Urea + Urease inhibitor, $80 \%$ dose of Urea + Urease inhibitor, and $80 \%$ dose of Urea + Urease inhibitor + Nitrification inhibitor also produced significantly higher number of tillers than control treatment (without inhibitors) in 4-6 WAP.

\section{Shallot Yield and Yield Component}

The yield components observed were the number and weight of shallot bulb (Table 2). The treatments of urease inhibitors and nitrification inhibitors did not affect the number and weight of shallot bulb. The highest number of shallot bulb (9 bulbs) produced by shallot treated with $100 \%$ dose of urea + Nitrification inhibitor. Shallot treated with $80 \%$ dose of urea + Urease inhibitor produced the least amount of shallot bulb, but produced the highest weight of shallot bulb compared to the other treatments.

Both treatments of urease and nitrification inhibitors did not effect on the yield of bulb/plants either wet bulb or dried bulb. The treatments with Urease and Nitrification inhibitors increased the yield/plant of shallot but the increase was not significantly different from the control. The yield per hectare showed that in general the application of urea fertilizer with urease and nitrification inhibitors did not affect the increase in shallot yield.

\section{Soil Analysis}

From the results of soil analysis, it was found that the treatment of urea with Urease and Nitrification inhibitors had no effect on $\mathrm{N}$-Total. Treatment of urea fertilizers with urease and nitrification inhibitors was found to increase soil N-Total. In the untreated, group (P0), the soil N-Total after the trial was slightly decreased, while the soil $\mathrm{N}$-Total in the treatment of fertilizer with or without inhibitors was found to increase. The percentage of total soil $\mathrm{N}$ after a trial in the treatment by the inhibitor was higher than the treatment without inhibitor (control). This result showed 
Table 2 Yield components and yields of shallot treated with urease and nitrification inhibitors

\begin{tabular}{|c|c|c|}
\hline Treatment & Number of Bulb/Plant & Weight of 10 Bulb $(\mathrm{g})$ \\
\hline Untreated & $6.1 \mathrm{a}$ & $40.3 a b$ \\
\hline $100 \%$ dose of Urea without inhibitor (control) & $8.5 a$ & $33.9 \mathrm{~b}$ \\
\hline $100 \%$ dose of urea + Urease inhibitor & $8.3 a$ & $36.0 \mathrm{~b}$ \\
\hline $100 \%$ dose of urea + Nitrification inhibitor & $8.8 \mathrm{a}$ & $43.2 \mathrm{ab}$ \\
\hline $\begin{array}{l}100 \% \text { dose of urea + Urease inhibitor + Nitrification } \\
\text { inhibitor }\end{array}$ & $8.1 \mathrm{a}$ & $39.2 \mathrm{ab}$ \\
\hline $80 \%$ dose of urea + Urease inhibitor & $5.3 a$ & $53.4 a$ \\
\hline $80 \%$ dose of urea + Nitrification inhibitor & $5.9 a$ & 43.9ab \\
\hline \multirow{3}{*}{$\begin{array}{l}80 \% \text { dose of urea + Urease inhibitor + Nitrification } \\
\text { inhibitor }\end{array}$} & $7.7 a$ & $42.2 \mathrm{ab}$ \\
\hline & \multicolumn{2}{|c|}{ Yield/plant (g) } \\
\hline & Fresh & Dry \\
\hline Untreated & $39.4 a$ & $20.7 a$ \\
\hline $100 \%$ dose of Urea without inhibitor (control) & $43.0 \mathrm{a}$ & $23.2 \mathrm{a}$ \\
\hline $100 \%$ dose of urea + Urease inhibitor & $44.2 a$ & $29.0 a$ \\
\hline $100 \%$ dose of urea + Nitrification inhibitor & $45.9 a$ & $27.3 a$ \\
\hline $\begin{array}{l}100 \% \text { dose of urea + Urease inhibitor + Nitrification } \\
\text { inhibitor }\end{array}$ & $42.8 \mathrm{a}$ & $20.6 a$ \\
\hline $80 \%$ dose of urea + Urease inhibitor & $39.3 a$ & $21.7 a$ \\
\hline $80 \%$ dose of urea + Nitrification inhibitor & $37.3 a$ & $17.7 \mathrm{a}$ \\
\hline \multirow{2}{*}{$\begin{array}{l}80 \% \text { dose of urea }+ \text { Urease inhibitor + Nitrification } \\
\text { inhibitor }\end{array}$} & $46.4 a$ & $24.7 a$ \\
\hline & Yield/25 m² (kg) & Yield/ha (kg/ha) \\
\hline Untreated & $17.0 \mathrm{~b}$ & $6800 \mathrm{~b}$ \\
\hline $100 \%$ dose of Urea without inhibitor (control) & $21.0 \mathrm{a}$ & $8400 a$ \\
\hline $100 \%$ dose of urea + Urease inhibitor & 19.3ab & $7733 a b$ \\
\hline $100 \%$ dose of urea + Nitrification inhibitor & $20.3 a$ & $8133 a$ \\
\hline $\begin{array}{l}100 \% \text { dose of urea + Urease inhibitor + Nitrification } \\
\text { inhibitor }\end{array}$ & $19.7 \mathrm{a}$ & $7867 a$ \\
\hline $80 \%$ dose of urea + Urease inhibitor & 19.0ab & $7600 \mathrm{ab}$ \\
\hline $80 \%$ dose of urea + Nitrification inhibitor & $19.7 a$ & $7867 a$ \\
\hline $80 \%$ dose of urea + Urease inhibitor + Nitrification & $19.7 a$ & $7867 a$ \\
\hline
\end{tabular}

Description: The numbers followed by the same letter in the same column are not significantly different according to DMRT on $5 \%$ level.

that $\mathrm{N}$ in the treatment given the inhibitor was still released after the shallot plant was harvested, so that $\mathrm{N}$ levels were still stored in plant tissue (Figure 1). Shallot is a short-lived plant and requires $\mathrm{N}$ during its lifetime, so the use of inhibitors is not effective. In the treatment without inhibitors (control), the total $\mathrm{N}$ content of the soil after the experiment was lower than the treatment with inhibitors. This shows that the total $\mathrm{N}$ in the treatment without inhibitors is lost from the soil because it is absorbed by plants, volatilization or dissolved in the flow of water (Figure 1). The efficiency of urea fertilizer is reduced by the presence of ammonia evaporation (Sangoi et al. 2016). To overcome these problems, plant residues are added to the soil in the no tillage system (Rojas et al. 2012).

Based on the results of the observation, the level of $\mathrm{N}$ in the treatment added with the inhibitor was higher than without the inhibitor (Table 3). Nitrogen in the treatment given the inhibitor was still not available to plants because it is still inhibited by urease and nitrification inhibitors. Urease and nitrification inhibitors cause the release of $\mathrm{N}$ available to plants to be slow. In addition, the age of shallot harvesting in this study was shorter (45 days) than the normal harvest age (60 days) due to the explosion of caterpillar pests, so that $\mathrm{N}$ added to the treatment given urease and nitrification

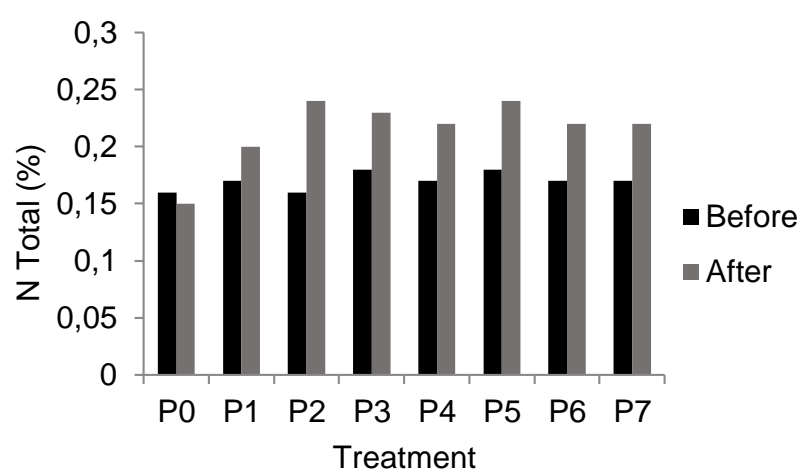

Figure $1 \mathrm{~N}$-total analysis results before and after treatment on soil; P0 (no treatment); P1 (100\% dose urea without treatment); P2 (100\% dose urea + urease inhibitor); P3 (100\% dose urea + nitrification inhibitor); P4 (100\% dose urea + urease inhibitor + nitrification inhibitor); P5 (80\% dose urea + urease inhibitor); P6 (80\% dose urea + nitrification inhibitor); and P7 (80\% dose urea + urease inhibitor + nitrification inhibitor).

inhibitors was not fully released (still in the form of urea). $\mathrm{N}$-Uptake is the result of multiplication between $\mathrm{N}$-content and dry yield/plants. N-Uptake for treatment with urease and /or nitrification inhibitors did not differ 
Table $3 \mathrm{~N}$ contents and $\mathrm{N}$ uptakes in bulb after harvesting

\begin{tabular}{lcc}
\hline \multicolumn{1}{c}{ Treatment } & N-Content (\%) & N Uptake (mg/plant) \\
\hline Untreated & $3.13 \mathrm{a}$ & $659.94 \mathrm{a}$ \\
$100 \%$ dose of Urea without inhibitor & $3.14 \mathrm{a}$ & $712.44 \mathrm{a}$ \\
$100 \%$ dose of urea + Urease inhibitor & $3.02 \mathrm{a}$ & $862.08 \mathrm{a}$ \\
$100 \%$ dose of urea + Nitrification inhibitor & $2.95 \mathrm{a}$ & $790.97 \mathrm{a}$ \\
$100 \%$ dose of urea + Urease inhibitor + Nitrification inhibitor & $2.83 \mathrm{a}$ & $587.71 \mathrm{a}$ \\
$80 \%$ dose of urea + Urease inhibitor & $2.83 \mathrm{a}$ & $613.09 \mathrm{a}$ \\
$80 \%$ dose of urea + Nitrification inhibitor & $2.91 \mathrm{a}$ & $501.30 \mathrm{a}$ \\
$80 \%$ dose of urea + Urease inhibitor + Nitrification inhibitor & $2.72 \mathrm{a}$ & $669.61 \mathrm{a}$ \\
\hline
\end{tabular}

significantly compared to the control treatment $(100 \%$ dose of urea without inhibitors) (Table 3 ).

\section{Discussion}

In trial on the application of urease inhibitors and nitrification inhibitors on shallot plants it could be seen that there were effects of inhibitor of both urease inhibitors and nitrification inhibitor in the variables of plant height, number of leaves and tillers, but had not significant effect on yield, yield component, and nitrogen content of plants. Treatments with $100 \%$ dose of Urea + Urease inhibitor, $80 \%$ dose of Urea + Urease inhibitor, $80 \%$ dose of Urea + Nitrification inhibitor, and $80 \%$ dose of Urea + Urease inhibitor + Nitrification inhibitors significantly produced higher plant height, number of leaves, and higher number of tillers compared to control group (100\% Urea rate without inhibitors). Some of the causes of the absence of inhibitor effects are due to the climate and soil types. According to Nelson \& Huber (2001), nitrification inhibitors are not very effective on sandy soil. Experiments were carried out in Brebes that had alluvial soil (sandy clay). In addition, the effectiveness of inhibitors will decrease if rainfall is high due to the leaching effect. The experiment was carried out in December-April which took place during the rainy season, so the effectiveness of inhibitors was low.

Both urease inhibitor and nitrification inhibitor should inhibit the release of nitrogen or nitrogencontaining fertilizers faster so they can be taken by plants during their lifetime and reduce nitrogen loss after becoming nitrate. Mohanty et al. (2008) state that urease inhibitor can reduce the rate of the first "hydrolysis" step, the rate of ammonia production and ammonia loss to the atmosphere.

There were some alternatives to minimize nitrogen losses i.e., slow-release nitrogen fertilizers, nitrification inhibitor, urease inhibitor, and etc. Slow release nitrogen fertilizers are fertilizers that are covered by hydrophobic chemicals so that it can provide a physical barrier against water. Nitrification inhibitors can delay $\mathrm{NH}_{4+}$ oxidation by nitrifying bacteria, preventing $\mathrm{NO}_{3}$ formation and nitrogen leaching from the soil (Akiyama 2010). Urease inhibitors can delay urea hydrolysis, increasing the chances of urea incorporation in soil (Artola 2011). The urease inhibitor such as $\mathrm{N}$-(n-butyl) thiophosphoric triamide (NBPT) added to urea was effective, easy method to reduce ammonium losses and increase the efficiency of $\mathrm{N}$ fertilization (Cantarella et al. 2008; Soares et al. 2012; Viero et al. 2015).
Plant nitrogen levels in plants treated with inhibitors were statistically not significant and the tended to be lower than treatments without inhibitors. It showed that the effect of inhibitors to inhibit nitrification activities so that nitrogen becomes available to plants. Unfortunately, the availability of nitrogen for plants was quite short and it did not affect the increase in shallot yields, because the 60 DAP should be harvested into 45 DAP. This young harvesting activity was due to the shallot caterpillar pest attack.

\section{CONCLUSION}

Based on research results showed that $100 \%$ dose of Urea + Urease inhibitor, $80 \%$ dose of Urea + Urease inhibitor, $80 \%$ dose of Urea + Nitrification inhibitor, and $80 \%$ dose of Urea + Urease inhibitor + Nitrification inhibitor treatments significantly produced more plant height, number of leaves, and more number of tillers compared to control treatment $(100 \%$ Urea rate without inhibitors), but it did not significantly affect the yield and yield component.

\section{ACKNOWLEDGEMENTS}

We would like to thank to Department of Agronomy and Horticulture, Faculty of Agriculture, Bogor Agriculture University for supporting this research.

\section{REFERENCES}

Akiyama H, Yan XY, Yagi, K. 2010. Evaluation of Effectiveness of Enhanced-efficiency Fertilizers as Mitigation Options for N2O and NO Emissions from Agricultural Soils: Meta-Analysis. Global Change Biology. 16: 1837-1846. https://doi.org/10.1111/ j.1365-2486.2009.02031.x

Artola E, Cruchaga S, Ariz I, Moran JF, Garnica M, Houdusse F. 2011. Effect of N-(n-butyl) Thiophosphoric Triamide on Urea Metabolism and The Assimilation of Ammonium by Triticum aestivum L. Plant Growth Regulation. 63: 73-79. https://doi.org/10.1007/s10725-010-9513-6

Cantarella H, Trivelin PCO, Contin TLM, Dias FLF, Rossetto R, Marcelino R, Coimbra RB, Quaggio JA. 
2008. Ammonia Volatilisation from Urease InhibitorTreated Urea Applied to Sugarcane Trash Blankets. Scientia Agricola. 65: 397-401. https://doi.org/ $10.1590 /$ S010390162008000400011

Du N, Chen M, Liu Z, Sheng L, Xu H, Chen S. 2012. Kinetics and Mechanism of Jack Bean Urease Inhibition by $\mathrm{Hg}^{2+}$. Chemistry Central Journal. 6(154): 1-7. https://doi.org/10.1186/ 1752-153X-6154

Juszkiewicz A, Zaborska A, Laptas A, Olech Z. 2004. A Study of The Inhibition of Jack Bean Urease by Garlic Extract. Food Chemistry. 85(4): 553-558. https://doi.org/10.1016/ j.foodchem.2003.07.033

[IPNI] International Plant Nutrition Institute. 2018. Urease Inhibitors. Georgia (US): IPNI.

[IPNI] International Plant Nutrition Institute. 2018. Nitrification Inhibitors. Georgia (US): IPNI.

Khan KM, Iqbal S, Lodhi MA, Maharvi GM, Mullahs Z. 2004. Biscoumarin: New Class of Urease Inhibitors; Economical Synthesis and Activity. Bioorganic \& Medical Chemistry. 12: 1963-1968. https:// doi.org/10.1016/j.bmc.2004. 01.010

Kuswantoro H. 2016. Potential Yield Of Acid-Adaptive Soybean Promising Lines In Ultisols Of Tanah Laut Regency, South Kalimantan Province, Indonesia. Biotropia. 23(1): 52-57. https://doi.org/10.11598/ btb.2016.23.1.561

Mishra H, Parrill AL, Williamson JS. 2002. Threedimensional quantitative structure-activity relationship and comparativemolecular field analysis on dipeptidehydroxamic acid $\mathrm{H}$. pylori urease inhibitors. Antimicrob. Agents Chemother. 46: 2613-2618. https://doi.org/ 10.1128/AAC. 46.8.2613-2618.2002

Mohanty S, Patra AK, Chhonkar PK. 2008. Neem (Azadirachta indica) seed kernel powder retards urease and nitrification activities in different soils at contrasting moisture and temperature regimes. Biresource Technology. 99: 894-899. https:// doi.org/10.1016/j.biortech. 2007.01.006
Nelson DW, Huber D. 2001. Nitrification inhibitors for corn production. National Corn Handbook Project. IOWA State University.

Prakash O, Bhushan G. 1998. A study of inhibition of urease from seeds of the water melon (Citrullus vulgaris). Journal of Enzyme Inhibition. 13: 69-77. https://doi.org/10.3109/ 14756369809035828

Rojas CAL, Bayer C, Fontoura SMV, Weber MA, Viero F. 2012. Volatilização de amônia da ureia alterada por sistemas de preparo de solo e plantas de cobertura invernais no Centro-Sul do Paraná. Revista Brasileira De Ciencia Do Solo. 36: 261-270. https://doi.org/10.1590/S010006832012000100027

Sangoi L, Silva PRF, Pagliarini NHF. 2016. Estratégias de manejo da adubação nitrogenada em milho na Região Sul do Brasil. Lages: Graphel.

Soares JR, Cantarella H, Menegale MLC. 2012. Ammonia volatilization losses from surface-applied urea with urease and nitrification inhibitors. Soil Biology Biochemistry. 52: 82-89. https:// doi.org/10.1016/j.soilbio.2012.04.019

Todd MJ, Hausinger RP. 1989. Competitive inhibitors of Klebsiella aerogenes urease: Mechanism of interaction with the nickel side. Journal of Biology Chemistry. 264: 15835-15842.

Tustiyani I, Sugiyanta, Melati M. 2014. Morphophysiology and Physicochemical Characters of Rice with Various Rates of Organic and Biological Fertilizer under Organic Farming System. Jurnal Agronomi Indonesia. 42(3) : 187194.

Uesato S, Hashimoto $\mathrm{Y}$, Nishino M, Nagaoka $\mathrm{Y}$, Kuwajima H. 2004. N-Substituted hydroxyureas as urease inhibitor. Chemical and Pharmaceutical Bulletin. 50: 1280-1282. https://doi.org/10.1248/ cpb.50.1280

Viero F, Bayer C, Vieira RCB, Carniel E. 2015. Management of irrigation and nitrogen fertilizers to reduce ammonia volatilization. Revista Brasileira De Ciencia Do Solo. 39: 1737-1743. https:// doi.org/10.1590/01000683rb cs20150132 